$\begin{array}{ll}\text { 総 説 } & 2008 \text { 年度口腔四学会合同研修会 } \\ \text { (社) 日本口腔外科学会 第 } 31 \cdot 32 \text { 回教育研修会 } \\ \text { 「感染症の基礎と臨床一最新の知見を中心に一」 }\end{array}$

\title{
口腔感染症に対する外科療法
}

\author{
梅田正博・古森孝英
}

\section{Surgical treatment for oral infectious disease}

\author{
UMEDA Masahiro · KOMORI Takahide
}

\begin{abstract}
Most of oral infectious diseases are polymicrobial including anaerobic organisms. Surgical procedure, as well as antibiotics treatment, is necessary especially for patients with severe infection. If proper therapy is not performed, oral infection is still potentially fatal disease.

Surgical procedure for severe oral infection requires enough understanding about anatomy of space around the jaws and neck, such as the sublingual space, the submental space, the submandibular space, the buccal space, the masticator space, the parapharyngeal space, the retropharyngeal space, and the retrovisceral space. When the parapharyngeal space is involved, infection often spreads through the retropharyngeal and retrovisceral spaces, and may lead to descending necrotizing mediastinitis.

Twenty-two patients with necrotizing fasciitis originated from oral infection were presented. The most frequent cause was infection of the mandibular molar region. Seven of the 22 patients had diabetes mellitus, although 11 had no general diseases. All patients were diagnosed to have necrotizing fasciitis by CT examination on the first day. Extensive debridement was undergone immediately, and all of them obtained good prognosis.
\end{abstract}

Key words: oral infectious disease（口腔感染症）, surgical treatment（外科療法）, necrotizing fasciitis（壊死性筋膜 炎), space (隙)

は じめに

抗菌薬の発達した今日でも口腔感染症は口腔外科医にと ってしばしば遭遇する疾患であり，治療法を䛊ると重症化 することもまれではなく，時に死に至ることすらある．口 腔感染症は主に嫌気性菌が関係する複数菌感染症である が, 嫌気性菌感染症の特徵の一つに膿瘍形成があり膿瘍内 には抗菌薬はほとんど移行しないため, 口腔感染症の治療 は適切な抗菌薬療法とともに外科療法が重要な位置を占め ている. 一方, 口腔感染症の最重症型である頸部壊死性筋 膜炎では膿瘍形成とともに組織破壊がみられ，早期に適切 な外科療法を行わないと, 短期間のうちに縦隔への波及や 敗血症ショック, 多臓器不全などを生じ予後不良となるこ とがある.

日本口腔感染症学会調査委員会が 2001 年に実施した多

神戸大学大学院医学研究科外科系講座口腔外科学分野

(主任：古森孝英教授)

Department of Oral and Maxillofacial Surgery, Kobe University Graduate School of Medicine (Chief: Prof. KOMORI Takahide)
施設共同前向き研究 ${ }^{1)}$ によれば, 初診患者のうち口腔感染 症患者の占める割合は, 一次機関（開業菊科）18施設で $9.6 \%$, 二次機関（病院茵科） 14 施設で $7.8 \%$, 三次機関 (大学病院） 2 施設で $10.2 \%$ あった. 感染症の内容とし ては，開業菊科では I 群（㐘周組織炎） $72.6 \%$ ，II 群（㐘 冠周囲炎） $17.8 \%$, III群 (顎炎) $5.0 \%, \mathrm{~N}$ 群（顎骨周囲の 蜂窩織炎） $0.6 \%$, V 群 (その他) $4.0 \%$ と, $90 \%$ 以上が I 群またはII群の比較的軽症例であったが, 病院柬科・大学 病院では I 群 $43.4 \%$ ，II 群 $21.4 \%$ ， III 群 $5.4 \% ，$ IV 群 $17.9 \%$, V群 $11.9 \%$, 重症の蜂窩織炎も多くみられたこ とが特徴的であったと報告されている.さらに同調查によ ると, 治療法として抗菌薬の投与とともに開業柬科では $49.5 \%$ と約半数に切開処置が施行されていたのに対し, よ り重症例の多い病院㐘科・大学病院では切開処置が併用さ れたのはわずかに $17.9 \%$ \%゙あったとも述べられている.こ れは, 病院では抗菌薬を点滴投与するためその効果が強く 切開なしでも治癒に導くことができる場合が多かったこと や，顔面や頸部皮膚に切開創を残すことがためらわれた場 合も少なくなかったためと推測できるが, 逆に外科処置が 
遅れたために下降性壊死性縦隔炎に移行した症例 2) や予 後不良となった症例 ${ }^{3)}$ の報告も散見される. 本稿では口腔 感染症のうち $I V$ 群（䫓骨周囲の蜂窩織炎）について, 外科 療法の適応や切開を行う際に必要な組織隙の解剖について 述べるとともに, 著者がこれまで経験した口腔感染症に起 因する頭頸部壊死性筋膜炎症例の概要について紹介する.

\section{口腔感染症の重症度判定と外科療法の適応}

口腔感染症の多くは, 嫌気性菌または嫌気性菌と微好気 性菌との複数菌感染症である. 嫌気性菌感染症は，1）慢性 /带急性の経過をとる，2）深在性である，3）組織の壊死を 伴う，4）悪臭のある分泌物が多い，5）膿瘍形成傾向が強 い，6）ガス産生性である，7）難治性である，8）単独感染 より複数菌感染が多い，などの特徵を有し，適切な抗菌薬 の選択とともに外科療法が推奨されている.さらに，口腔 感染症は傍咽頭隙などに波及して開口障害や気道閉塞を生 じたり，さらに咽後間隙（咽頭後隙，後咽頭隙）に波及す ると頸部を通過して下降性縦隔炎を生じることがあること を念頭に置く必要がある.

一般に感染症の診断には，1）炎症所見（発赤, 腫脹, 疼 痛, 熱感など),2）臟器所見，3）起炎菌の同定の三者が必 要である.さらに感染症の重症度は, 白血球数, 分画と CRPにより判定されるが，これらの血液検査は通常の病院 では 30 分程度で結果が出るため非常に有用である. CRP は $0.1 \mathrm{mg} / \mathrm{dl}$ 以下では炎症なし， $0.1 \sim 1.0 \mathrm{mg} / \mathrm{dl}$ では炎症 はあるが軽度, $1.0 \sim 10.0 \mathrm{mg} / \mathrm{dl}$ では中等度, $10 \mathrm{mg} / \mathrm{dl}$ 以上 では重症感染症の可能性があると判定される. 金川 ${ }^{4)}$ は $\mathrm{CRP}$ が $10 \mathrm{mg} / \mathrm{dl}$ の場合は入院管理の適応， $20 \mathrm{mg} / \mathrm{dl}$ では 緊急性を要すると述べており, 米国感染症学会の皮膚・軟 組織感染症診断・治療ガイドライン ${ }^{5)}$ では CRP が $13 \mathrm{mg} / \mathrm{dl}$ 以上の場合は入院管理を検討するべきと記載され ている.

一方, 全身性炎症反応症候群 (systemic inflammatory response syndrome: SIRS）という概念がある.これは侵襲 に対する全身性反応で, 1) 体温 $>38{ }^{\circ} \mathrm{C}$ まは $\left.236{ }^{\circ} \mathrm{C}, 2\right)$ 心拍数 $>90 / \mathrm{min}, 3)$ 呼吸数 $>20 / \mathrm{min}$ または $\mathrm{PaCO}_{2}<$ $32 \mathrm{mmHg}$ ，4）白血球数 $>12,000 / \mathrm{mm}^{3}$ または $<4,000 /$ $\mathrm{mm}^{3}$ ，あるいは未熟顆粒球> $10 \%$ \%うち 2 項目以上が該 当する場合に本症候群と診断され，敗血症打よびその周辺 病態への entry criteria とされている. 敗血症 (sepsis) と は感染によるSIRS と定義されて打り，血中の細菌同定の 有無は診断上必須項目ではない，さらに敗血症のうち臟器 機能障害, 循環不全 (乳酸アシドーシス, 乏尿, 急性意識 障害など)，血圧低下（収縮期血圧 $<90 \mathrm{mmHg}$ または平時 の収縮期血圧より $40 \mathrm{mmHg}$ 以上の血圧低下）などの症状 が出現したものは重症敗血症（severe sepsis），適切な補液 でも血圧低下が持続する場合や血管作動薬使用により血圧 が維持されていても藏器機能障害・循環不全 (乳酸アシド ーシス, 乏尿, 急性意識障害など）があるものは敗血症性 ショック（septic shock）と定義されている.

これらのことから, 口腔感染症では明らかな膿瘍形成が ある場合に加え，1）CRP や白血球数が著しく高値を示す 場合，2）SIRS，敗血症に該当する場合，3）開口障害が強 く傍咽頭隙や咽後間隙への波及が疑われる場合，4）後述 の壊死性筋膜炎が疑われる場合などには，適切な抗菌薬治 療とともに早期の外科処置が必要である.

\section{口腔周囲の組織隙の解剖}

口腔感染症に起因する膿瘍を切開する場合には, 皮膚あ るいは口腔粘膜に切開を加えモスキート等で鈍的に膿瘍腔 まで剥離を行うと容易に排膿が得られる（図 1). 顎骨周囲 の蜂窩織炎の場合には, 必ず CT を撮影し, 炎症が波及し ている部位を確認した上で，適切な組織隙を開放すること が必要である. 次に口腔周囲の組織隙について解説する.

\section{1 ) 舌下隙 (sublingual space) (図 2)}

顎舌骨筋よりも上方で下顎骨体とオトガイ舌筋に囲まれ た組織隙で, 顎下隙や咀嚼筋隙と交通する. 舌下隙に炎症 が波及すると, 口底部の腫脹・発赤・二重舌を呈する. 舌 下隙膿瘍の切開方法は，口底粘膜を切開し鈍的に深部に向 かって剥離すると, 容易に舌下隙に到達, 排膿が得られる.

\section{2 ) オトガイ下隙（submental space）(図 3)}

左右の顎二腹筋前腹内側縁と舌骨体で囲まれた三角形の 部分で, 上方は㖽舌骨筋下面, 下方は深頸筋膜浅葉の間に ある組織隙で, 顎下隙と交通する.オトガイ下隙に炎症が 波及すると，オトガイ部から前頸部の発赤・腫脹を呈する が,オトガイ下隙に限局した炎症は開口障害をきたさない. オトガイ下隙膿瘍の切開方法は, オトガイ部の下䫟下縁で 皮膚切開し，鈍的に皮下脂肪層打よび左右の広頸筋の間を 剥離するとオトガイ下隙に到達, 排膿が得られる.

\section{3 ) 顎下隙 (submandibular space) (図 4)}

下顎骨体の内側下方で顎舌骨筋より下部に位置し, 顎下 腺と顎下リンパ節の存在する組織隙で, 舌下隙・オトガイ 下隙・咀嚼筋隙と交通している。顎下隙に炎症が波及する と, 患側下顎下縁から上頸部の発赤・腫脹と開口障害を呈 する. 顎下隙膿瘍の切開方法は, 下顎下縁より $1.5 \sim 2 \mathrm{~cm}$ 離して皮膚切開し, 下層の広頸筋・浅頸筋膜を切離した後, 鈍的に口底方向へ剥離すると排膿が得られる。 

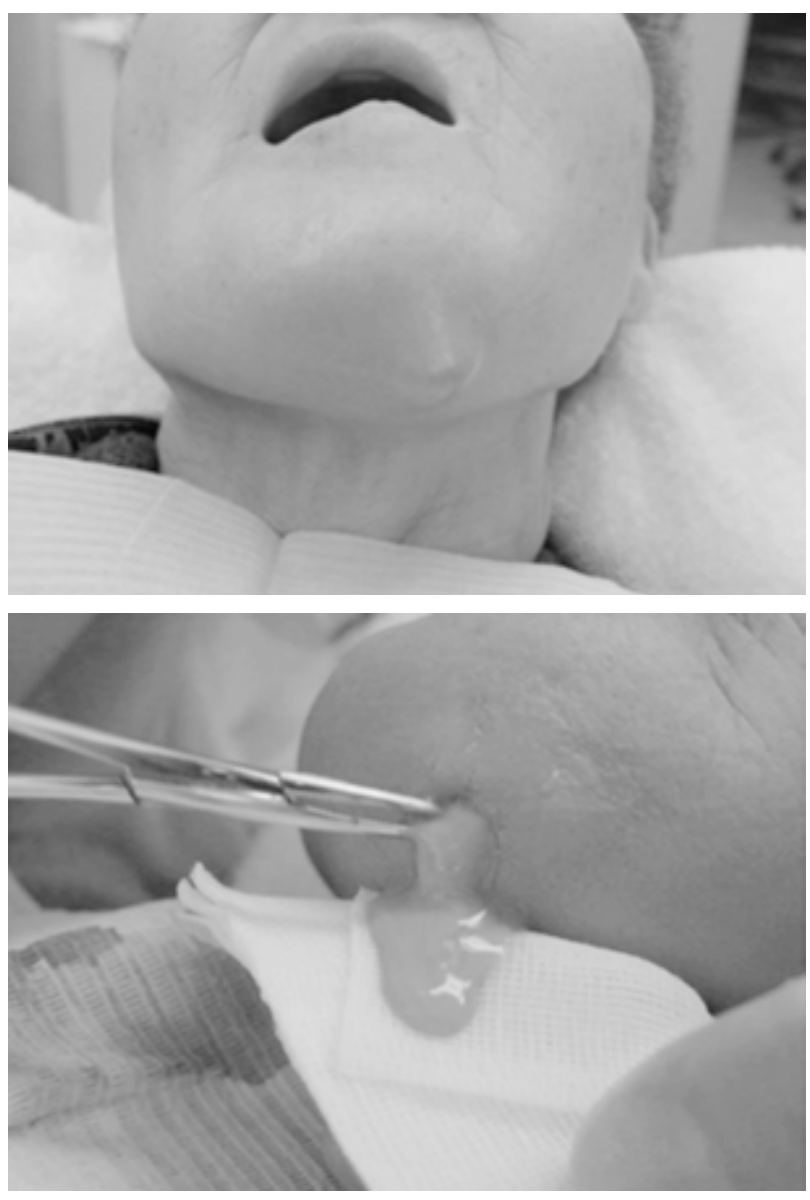

図 1 オトガイ部膿瘍の切開 表層の膿瘍では容易に排膿が得られる。

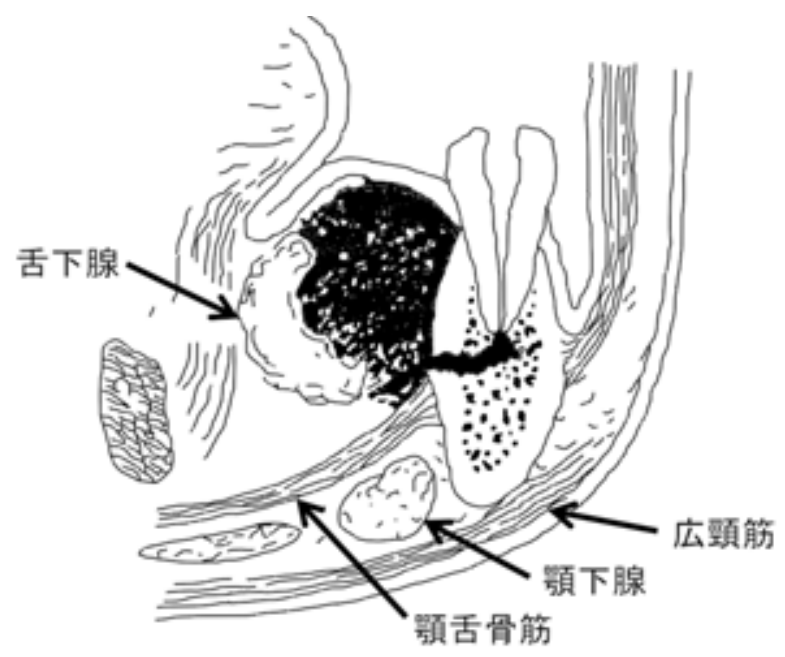

図 2 舌下隙膿瘍の模式困

\section{4 ) 頓隙 (buccal space) (図 5)}

煩筋と咬筋との間にある脂肪分に富んだ部分で，上方は 煩骨側頭隙, 後方は咀嚼筋隙に交通する. 煩隙に炎症が波

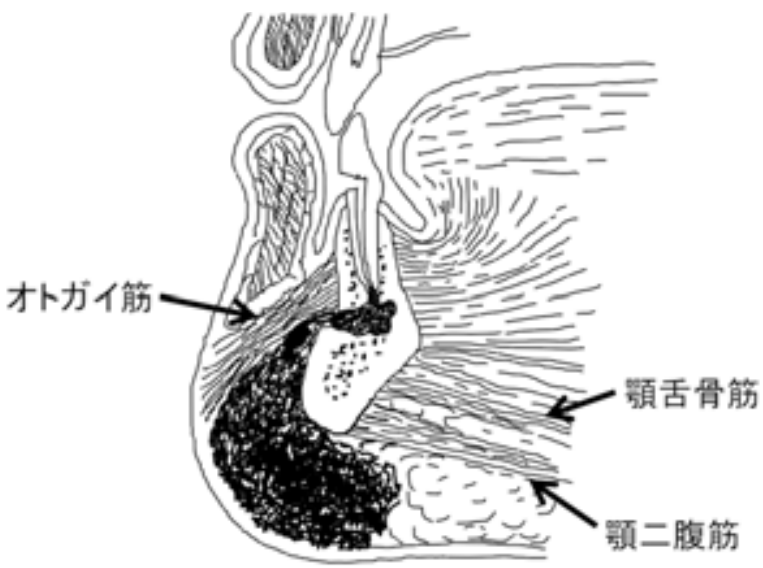

図 3 オトガイ下隙膿瘍の模式困

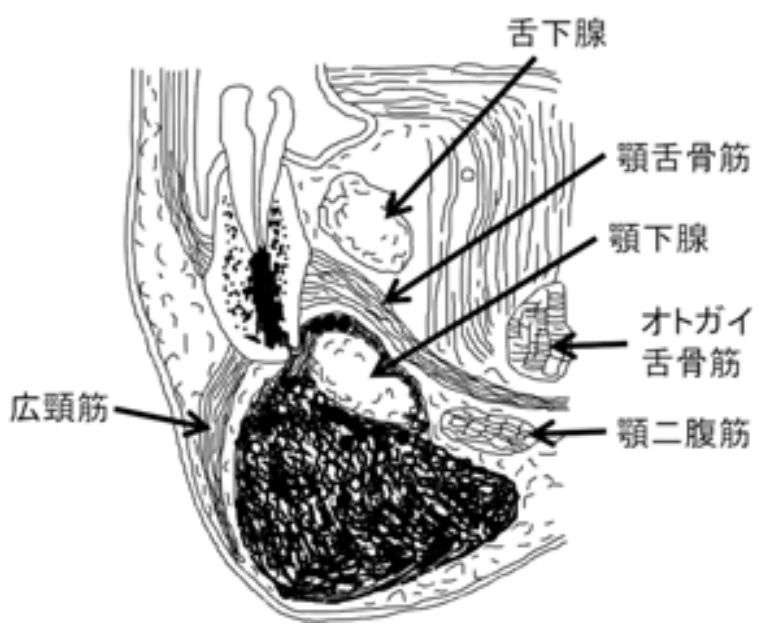

図 4 顎下隙膿瘍の模式図

及すると顔面煩部の腫脹・発赤を生じるが，開口障害は軽 度に認めるのみである. 煩隙膿瘍の切開方法は, 口腔粘膜 または煩部皮膚を切開, 鈍的に深部に剥離を行う。

\section{5 ) 咀嚼筋隙 (masticator space) (図 6)}

深頸筋膜浅葉が下顎に達し，そこから分かれて咬筋筋膜 と翼突筋膜になるが，その両者に囲まれる隙. 外側の上方 では煩骨弓に付着する咬筋筋膜が深側頭筋膜浅葉に移行, 一方, 筋突起に付着する側頭筋膜は深側頭筋膜深葉に移行 し，両葉間に側頭隙（temporal space）を形成するが，最終 的に側頭筋の頭蓋骨付着部 (側頭線) で頭蓋骨膜に移行す る. 内側の境界は煩咽頭筋膜で, 深部は内側翼突筋膜が翼 状突起外側板内側面から棘孔内側の中頭蓋底骨に付着し, 傍咽頭隙とを区別している．前方では煩隙と連続する．咬 筋筋膜は咬筋の下顎骨付着部前方と下顎枝の前方に沿った 


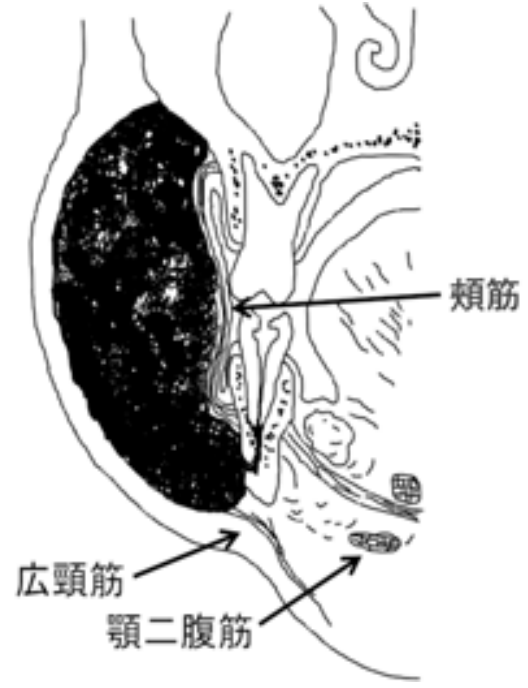

図 5 煩隙膿瘍の模式図

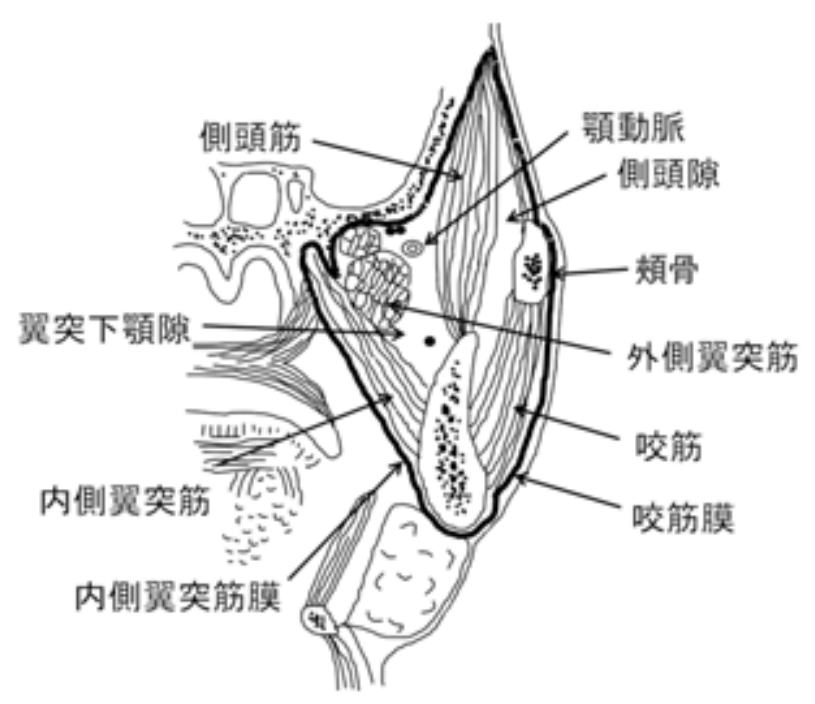

図 6 咀嚼筋隙の模式図 文献 6）を一部改変.

側頭筋の停止部に付着する。さらに下顎枝の前方を通り， 煩脂肪体の外表面を横切り，上顎およびその下方の煩筋筋 膜に連続する. 後方では下顎の後方, 胸鎖乳突筋の前縁で 耳下腺筋膜に接する.

咀嚼筋隙には下顎骨と咀嚼筋，三叉神経第 3 枝が含まれ る. 対応する側頭窩，側頭下窩にならい，煩骨弓より上を 側頭隙 (煩骨上咀嚼筋隙)，煩骨弓より下を側頭下窩（煩 骨下咀嚼筋隙）と区別することもある.また，特に下顎枝 と内側翼突筋の間を翼突下顎隙と細分することもあるが, 翼突下顎隙は下顎大臼柬部の茵性感染症や腫瘍の進展経路 として特に重要な隙である。さらに翼突下顎陌には舌神経

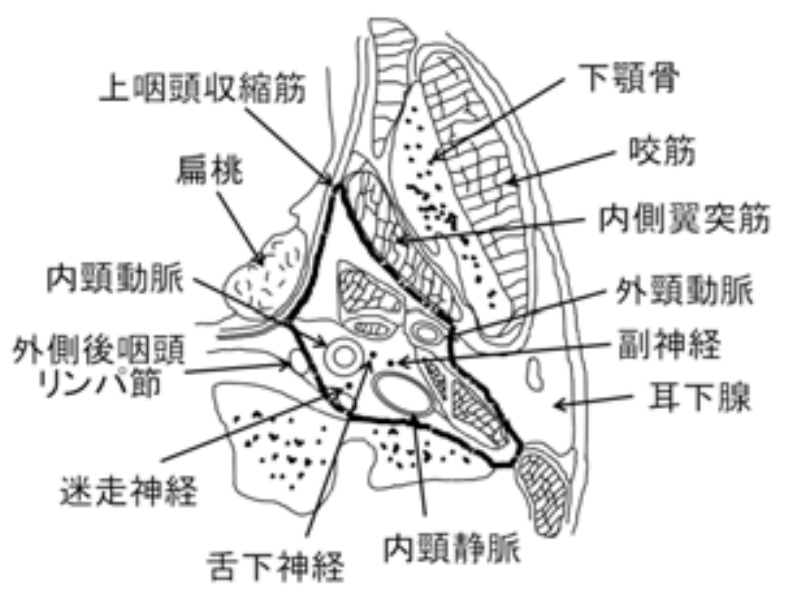

図 7 傍咽頭隙の模式困 文献 7）を一部改変.

や下柬槽神経, 動静脈が走行しており，下顎孔の伝達麻酔 を行う場所でもある。

咀嚼笳隙に炎症が波及すると，部位にもよるが，煩部の 腫脹や強度の開口障害を呈する。咀嚼筋隙膿瘍の切開方法 は部位によりさまざまな方法があり，口腔内より切開でき る場合もあるが，上方に進展した場合は煩骨弓下や側頭部 から皮膚切開を行う。

\section{6 ) 傍咽頭隙（parapharyngeal space）(図 7)}

内側翼突筋内面と咽頭収縮筋で囲まれた部分の組織隙. 顎下隙や咀嚼笳隙と交通し, 後方内側に位置する後咽頭隙 とも交通している，傍咽頭隙に炎症が波及すると，強度の 開口障害・嚥下痛，口蓋弓・軟口蓋の発赤・腫脹を呈する. 気道閉塞をきたすこともあり注意を要する. 傍咽頭隙膿瘍 の切開方法は，下顎角部から皮膚切開して広頸筋を切断し 顎下腺を前方に翻転，後方の下顎骨内面に到達し，鈍的に 内側翼突筋の内側に沿って剥離する. 気道閉塞が強度の場 合は気管切開が必要になることもある。傍咽頭隙の炎症は 後述の咽頭後隙に波及し, 後咽頭隙を経由して縦隔洞へ波 及することがあるので，十分な注意が必要である.

\section{7 ）咽後間隙（図 8）}

咽頭は頸椎の前方に位置し, 頸椎と咽頭粘膜の間にはい くつかの筋膜で区別された疎な組織があり，咽後間隙と呼 ばれる，咽後間隙にはその解剖学的構造から，咽頭後陌， 後咽頭隙, 前脊椎隙の 3 者に分けられる.このうち咽頭後 隙と後咽頭隙は口腔感染症の波及を考えるときに重要な組 織隙である。

咽頭後隙（retropharyngeal space）は上咽頭収縮筋の後 


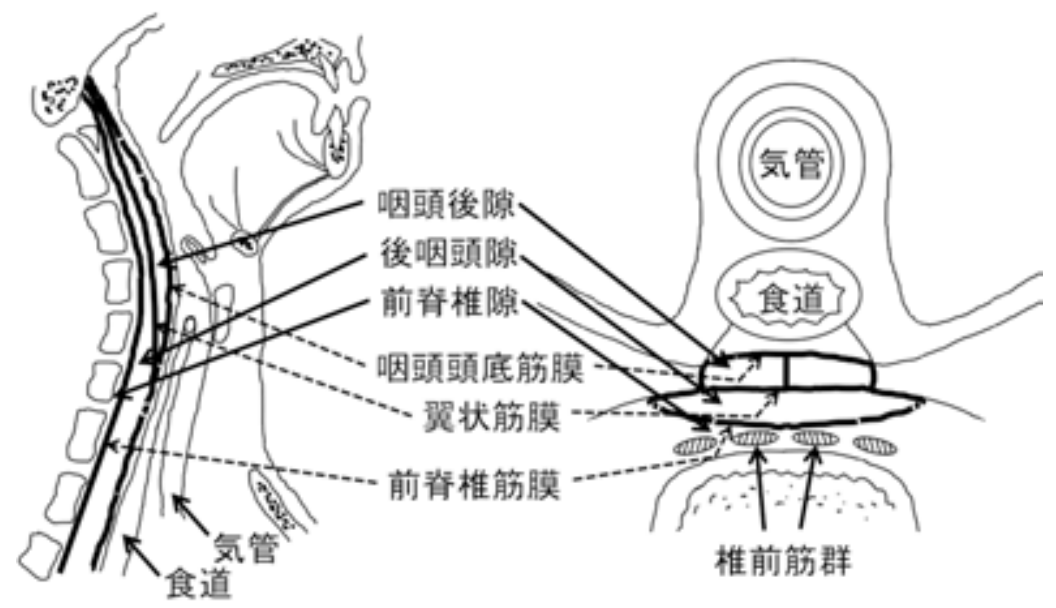

図 8 咽後間隙の模式図

文献 8）を一部改変.

方に位置し，咽頭頭底筋膜と翼状筋膜で囲まれた左右一対 の組織隙である. 中央は線維性支柱で隔絶されている. 側 方は内頸動静脈や迷走神経まで, 上方は上咽頭収縮筋頭蓋 底付着部まで, 下方は破裂軟骨の高さまでを占める. 咽頭 後隙には脂肪組織とリンパ節が存在するが, 特に外側上方 には咽頭後リンパ節（ルビエールリンパ節）がある.

後咽頭隙（retrovisceral space）は咽頭後隙の後方に位置 し，翼状筋膜と前脊椎筋膜で囲まれた組織隙で，上方は第 一頸椎から始まり, 下方は食道後腔を経由し縦隔洞まで続 いている．咽頭後隙からの炎症がこの隙に及ぶと，容易に 縦隔洞まで波及する危険があることから，別名危険隙 (danger space) とも呼ばれる.

深頸部膿瘍，壊死性筋膜炎などの感染症が頸部の隙を下 降し，縦隔洞へ進展したものを，特に下降性壊死性縦隔炎 と呼ぶ. 口腔の感染が縦隔へ至る経路には, (1)前頸部, 舌 骨から上縦隔へ至る経路，(2)傍咽頭隙を経由し頸動脈周囲 を下降する経路，(3)咽後間隙（咽頭後隙 $\rightarrow$ 後咽頭隙）を下 降する経路の三者があるが，多くは(3)の咽後間隙を経由す る.したがって, 㐘性感染症が傍咽頭隙まで及ぶと, 咽頭 後隙, 後咽頭隙を経由して縦隔洞炎を引き起こしやすく致 命的となる可能性があるので, 特に注意が必要である.

\section{壊死性筋膜炎の治療方法}

壊死性筋膜炎は主に嫌気性菌などの複数筋感染によって 生じる皮下組織あるいは筋膜に沿った軟組織感染症で，急 激な組織壊死とガス産生を特徴とする. 発生頻度はまれで, 糖尿病などの全身疾患を有する者に発症しやすいが，特に 既往歴のない若壮年者にも発症することがある. 頭頸部の 壊死性筋膜炎の原因として㐘性感染症は最も頻度が高く,

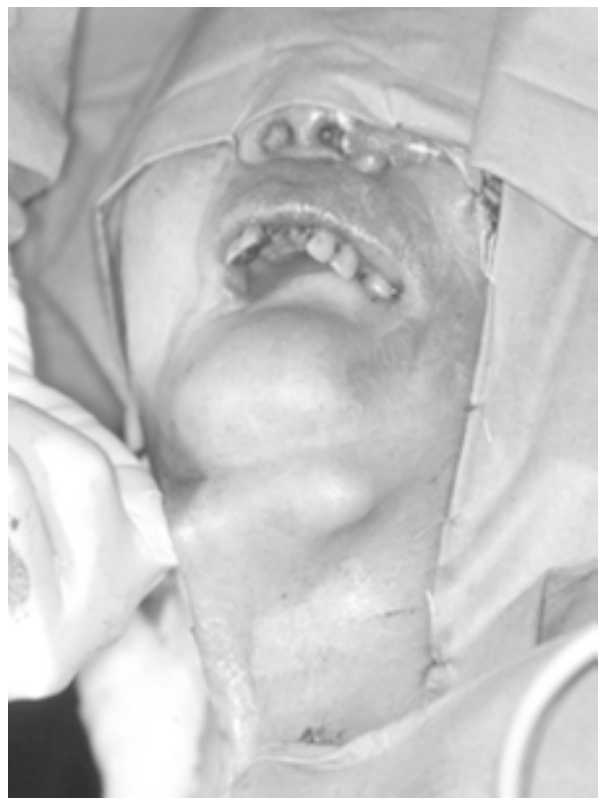

図 9 顎下隙壊死性筋膜炎の術中所見 オトガイ下隙を手指にて開放しているところ

早期に外科処置を含めた適切な治療が施されないと時に致 死的な経過を辿ることがあり，㐘科口腔外科医はその病態 や治療法について熟知しておく必要がある.

壊死性筋膜炎の診断には CT によるガス像の証明が非常 に有用であるとともに, 切開手術の術式を検討する上でも CT による進展範囲の把握は欠かせない，壊死性筋膜炎の 診断が下されたら，適切な抗菌薬の投与とともに直ちに外 科処置を行うことが望ましい. 壊死性筋膜炎に対する抗菌 薬としては好気性, 嫌気性両者に有効なものが選択される が, 米国感染症学会 (Infectious Diseases Society of 
表1 壊死性筋膜炎症例

\begin{tabular}{|c|c|c|c|c|c|c|c|c|}
\hline 年齢・性 & 因 & $\begin{array}{c}\text { 白血球数 } \\
(/ \mu 1)\end{array}$ & $\begin{array}{c}\text { CRP } \\
(\mathrm{mg} / \mathrm{dl})\end{array}$ & 主な全身疾患 & 手術日 & 麻酔 & 気道確保 & 予後 \\
\hline 1（35·男） & 下顎智歯抜歯後感染 & 14200 & 25.0 & - & 当日 & 局麻 & - & 良好 \\
\hline 2（67·男） & 下顎臼菊per & 38700 & 26.0 & - & 当日 & 全麻 & - & 良好 \\
\hline 3 (46·女) & 下顎智歯抜歯後感染 & 16600 & 14.3 & - & 当日 & 全麻 & 気切 & 良好 \\
\hline 4 (62·女) & 下顎前歯per & 16200 & 16.7 & 糖尿病、腎不全、心不全 & 当日 & 全麻 & 気切 & 他病死 \\
\hline 5 (60・女) & 上顎臼㐘per & 12400 & 12.4 & - & 当日 & 全麻 & - & 良好 \\
\hline 6 (60・女) & 上顎臼㐘per & 13100 & 22.3 & 糖尿病 & 当日 & 局麻 & - & 良好 \\
\hline 7（77·男） & 下顎臼柬部放射線骨壊死 & 22100 & 18.9 & - & 当日 & 全麻 & 気切 & 良好 \\
\hline 8 (72·女) & 下顎臼柬部放射線骨壊死 & 11800 & 9.03 & - & 2日後 & 全麻 & 気切 & 良好 \\
\hline 9 （48・男） & 下顎臼柬per & 11600 & 54.3 & 糖尿病、統合失調症 & 当日 & 全麻 & 気切 & 良好 \\
\hline 10 (76·女) & 下顎臼蒾部骨髄炎 & 24500 & 28.0 & 潰瘍性大腸炎（ステロイド） & 当日 & 全麻 & 気切 & 良好 \\
\hline 11 (63·男) & 下顎臼柬per & 18300 & 14.8 & アルコール依存症 & 当日 & 全麻 & 気切 & 良好 \\
\hline 12 (60·女) & 上顎臼柬per & 13100 & 22.3 & 糖尿病 & 当日 & 全麻 & - & 良好 \\
\hline 13 (67·男) & 下顎臼歯per & 19600 & 14.6 & - & 当日 & 全麻 & 気切 & 良好 \\
\hline 14（58·男) & 下顎臼㐘per & 8500 & 23.4 & 糖尿病 & 当日 & 全麻 & 気切 & 良好 \\
\hline 15 (81·女) & 下顎臼柬部Dul & 19900 & 25.3 & 糖尿病、心不全、認知症 & 当日 & 全麻 & 挿管 & 良好 \\
\hline 16（55・男） & 下顎前柬per & 23300 & 17.6 & 前立腺肥大、不整脈 & 当日 & 全麻 & - & 良好 \\
\hline 17 (63·女) & 下顎前歯per & 20800 & 35.6 & 糖尿病 & 当日 & 全麻 & - & 良好 \\
\hline 18（67・男） & 下顎臼柬per & 38700 & 25.0 & - & 当日 & 全麻 & - & 良好 \\
\hline 19 (68·男) & 下顎智柬perico & 25800 & 28.1 & 関節リウマチ（ステロイド） & 当日 & 全麻 & 挿管 & 良好 \\
\hline 20 (82·女) & 下顎臼歯抜歯後感染 & 12700 & 11.7 & - & 当日 & 全麻 & 気切 & 良好 \\
\hline 21 (33·女) & 下顎智蒾per & 21100 & 14.9 & - & 当日 & 全麻 & 気切 & 良好 \\
\hline 22 (28·男) & 下顎智㐘perico & 11800 & 33.7 & - & 翌日 & 全麻 & 気切 & 良好 \\
\hline
\end{tabular}
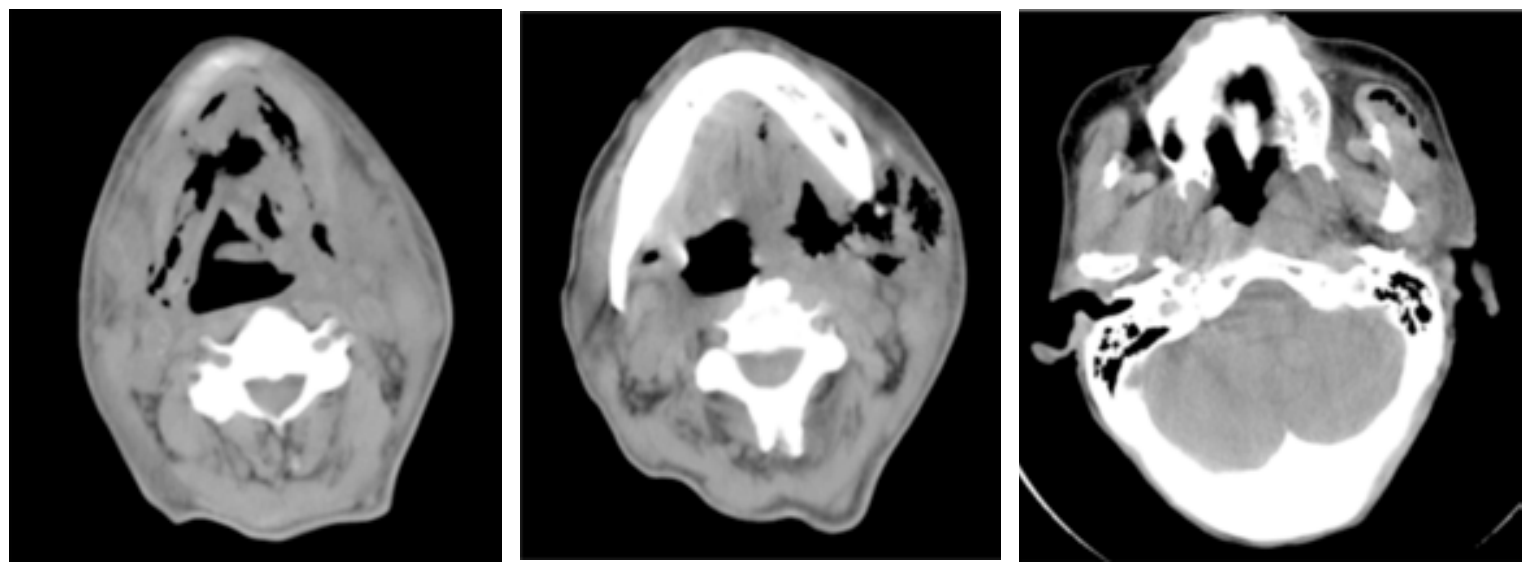

図 10 顎下隙，オトガイ下隙，咀嚼筋隙，傍咽頭隙の壊死性筋膜炎（症例 15） 広範なガス像を認める.

America）のガイドライン 5) では ampicillin/sulbactam + clincamycin + ciprofloxacinの三剤併用が推奨されている. また，嫌気性菌感染症診断・治療ガイドライン（日本化学 療法学会・日本嫌気性菌感染症研究会) ${ }^{9)}$ では imipenem/ cilastatin や ampicillin + clindamycin が推奨されている. 外科処置としては通常の膿瘍のような局所麻酔下での皮膚 切開では不十分であり, 炎症が進展している最前線まで適
切に組織隙を開放し, 壊死組織を十分に择爬することが重 要である. 組織隙の開放には手指を用いた剥離操作が安全 で有効である（図 9). 傍咽頭隙や咽後間隙への進展が疑わ れる場合や全身状態が不良な場合には気管切開による気道 確保を行う．舌骨より下方の前頸部には㖽骨周囲につなが る組織隙は存在しないため, 下気管切開は安全に施行する ことができる. 


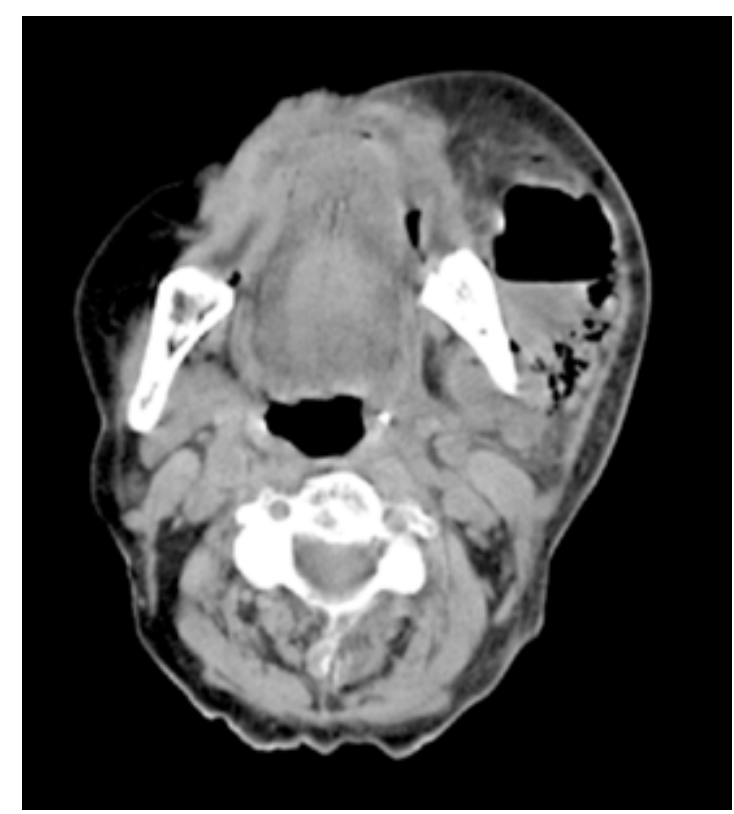

図 11 煩隙の壊死性筋膜炎（症例 10） 煩隙に大小のガス像を認める.
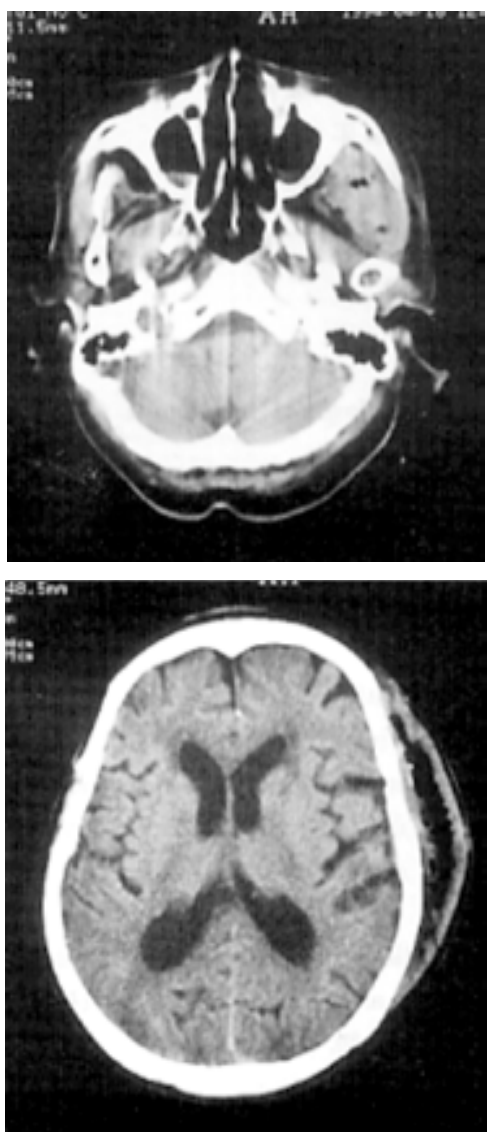

図 12 咀嚼筋隙, 側頭隙の壊死性筋膜炎（症例 20） $\sqrt{6}$ 抜歯後感染から側頭隙まで至った 1 例.

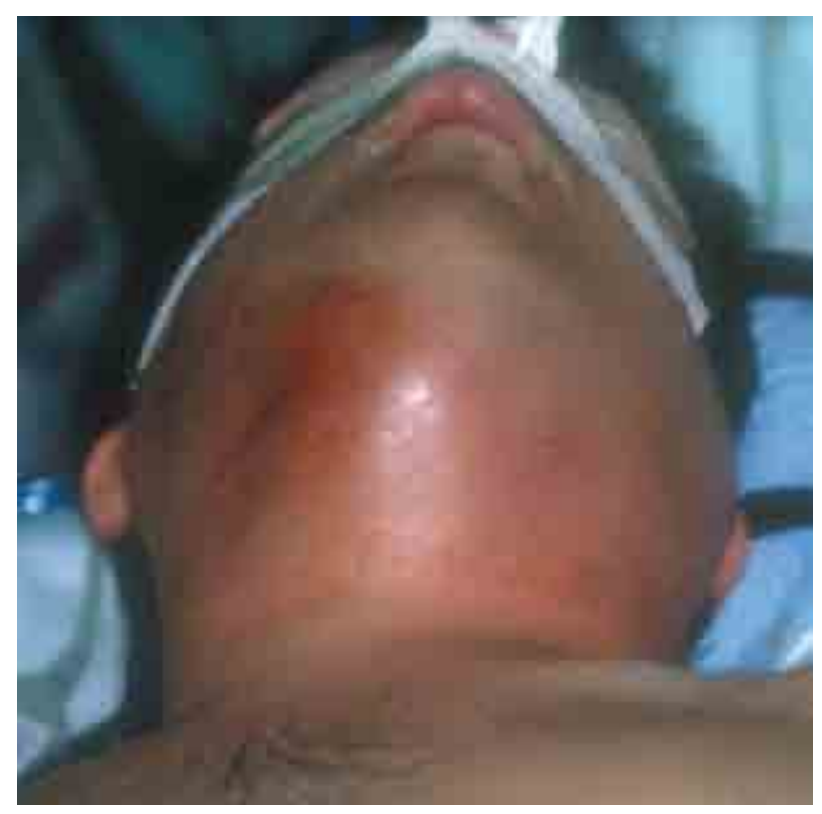

図 13 症例 9 の初診時顔貌所見 両側頸部の発赤, 腫脹を認める.

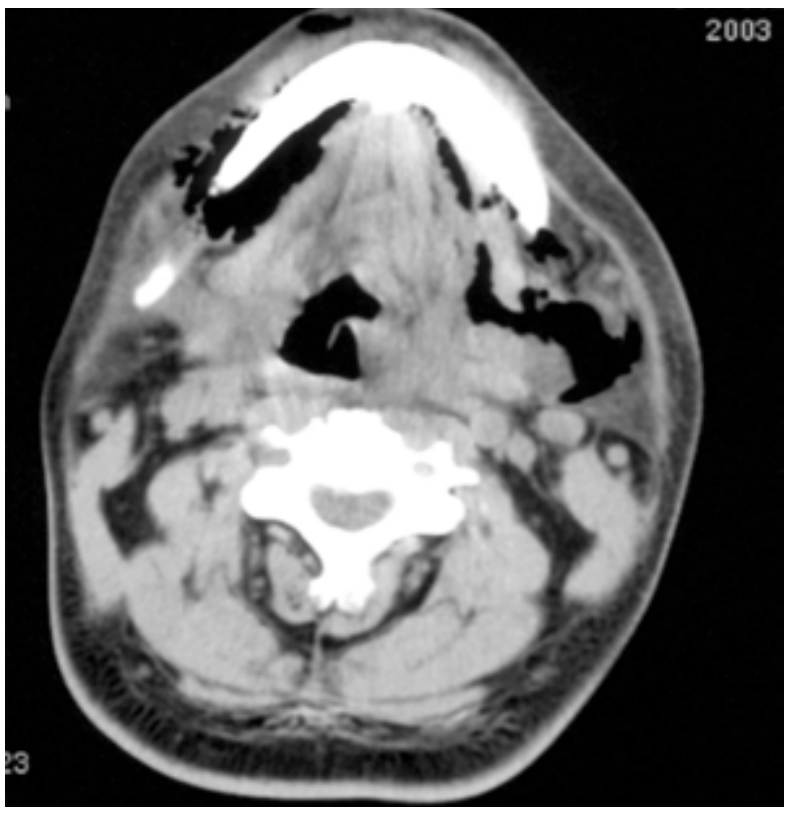

図 14 症例 9 の CT1 像

$\sqrt{6}$ per から両側顎下隙, 左傍咽頭隙に及んだ壊死性筋 膜炎の 1 例.

著者らは以前茵性感染症に起因する頭頸部壊死性筋膜炎 の報告例について検討した ${ }^{10,11)}$. 約 $20 \%$ が死の転帰をと つていたが，糖尿病などの基礎疾患を有するもの，初診か ら外科処置までの時間が 24 時間以上を要したもの, 縦隔 への進展のみられたものでは有意に予後不良となってお り, 早期の外科処置の重要性が再確認された. 
著者がこれまで経験した壊死性筋膜炎症例 22 例の概要 を表 1 に示した. 性差はなく年歯令は 35 ～ 82 歳（平均 60.4 歳)，下顎曰柬部の炎症に起因したものが多く，原因疾患は 根尖性柬周炎が 13 例，抜柬後感染が 3 例，智柬周囲炎，放 射線骨壊死が各 2 例，義柬裖創性潰瘍，骨髄炎が各 1 例で あった。初診時臨床検査では，白血球数は 8,500 $38,700 / \mathrm{mm}^{3}$ (平均 $18,855 / \mathrm{mm}^{3}$ ) と高く, 22 例中 18 例が 前述の SIRS の診断基準である $12,000 \mathrm{~mm}^{3}$ 以上を示してい た. $\mathrm{CRP} も 9.03 \sim 54.3 \mathrm{mg} / \mathrm{dl}$ (平均 $22.5 \mathrm{mg} / \mathrm{dl}$ ) と高く, 22 例中 21 例が $10 \mathrm{mg} / \mathrm{dl}$ 以上， 12 例が $20 \mathrm{mg} / \mathrm{dl}$ 以上の著 しい高值を示していた．主な全身疾患としては糖尿病が 7 例，ステロイド服用中が 2 例にみられたが，半数の 11 例で は特に全身疾患の合併はなかった。全例初診当日に入院さ せ CT でガス像の確認ができ，壊死性筋膜炎の診断が下さ れた (図 $10 \sim 12$ ). 抗菌薬は ampicillin/sulbactam + clincamycin または imipenem/cilastatin などの経静脈投与が選 択されることが多く，22 例中 21 例は初診当日に，1例は 2 日後に外科処置が行われた. 麻酔方法は 20 例と大多数で 全身麻酔下が施行され，気道確保として 12 例で気管切開 が同時に行われた. 予後は消炎後に腎不全および心不全の 治療目的で内科に転科となった 1 例で 6 か月後に他病死と なったが，他の 21 例は軽快退院となった。早期の徹底した 外科処置が有効であったと考えられた。代表例を供覧する。

患者（表 1 の症例 9）は48歳男性で，1 週間前より左顎 下部腫脹と開口障害を自覚，放置していたが症状が増悪す るため近医柬科を受診，ただちに当科を紹介された。既往 歴に統合失調症および未治療の糖尿病を認めた. 初診時両 側頸部に腫脹と発赤を認め (図 13), 体温 $38.4{ }^{\circ} \mathrm{C}$, 脈拍数 108 回/分で, 臨床検査では白血球数 $11,600 / \mathrm{mm}^{3}, \mathrm{CRP}$ $54.3 \mathrm{mg} / \mathrm{dl}$ と著しい炎症所見を認めた。また，血糖值 648 $\mathrm{mg} / \mathrm{dl}, \mathrm{HbA1c} 12.7 \%$ と重度の糖尿病の所見を呈していた。 CT ではオトガイ下陌から両側顎下隙を中心に広範なガス 像を認め, 左傍咽頭隙も腫脹のため咽頭腔の狭窄を認めた （図 14）。 6 の根尖性柬周炎に起因する頸部壊死性筋膜炎 および敗血症と診断した. 意識レベルの問題はないものの, 管理不十分な統合失調症があるため病識も乏しく，治療に 対して非協力的であったため，家族に処置の緊急性を十分 に説明した上で，外来にて鎮静剤の投与を行い手術室に搬 送, 全身麻酔下に気管切開, 両側顎下隙, オトガイ下隙, 左 傍咽頭隙の開放およびデブリードマンを行った. 術中所見 として，皮膚切開直後に強い腐敗臭を伴う黒褐色〜灰色の 壊死組織を認めた。手指で十分に隙の開放を行い，ペンロ
ーズドレーンを挿入，開放創のまま手術を終了した。抗菌 薬は panipenem/betamipron（PAPM/BP）および cefazolin（CEZ）を投与し，術後の細菌検查では Streptcocci, Bacteroides oralis が検出された。統合失調症を有していた ため，術後 3 日間は鎮静，人工呼吸管理を行い，糖尿病に ついてはインスリンによるコントロールを行った，その後 炎症は良好に消退したが, 栄養チューブやバルンカテーテ 儿の予定外抜去，看護師への暴力などの不穏行動がみられ たため精神科に転科となり, 90 日後に軽快退院となった。

\section{結語}

口腔感染症の外科療法を行う際に必要な組織隙について 解説するとともに，重症度の判定，外科療法の適応，壊死 性筋膜炎の治療法などについて報告した。

\section{引用 文 献}

1）大塚芳基：口腔感染症の実態調査報告. 口腔感染症 誌 9: 25-27 2002 .

2）赤松栄之, 佐野寿哉, 他：歯性感染症より生じたガ 又壊疽の 1 例. 日口診誌 21: 112-116 2008.

3）川越弘就，吉位 尚，他：下顎智柬の抜歯後感染か ら頸部ガス壊疽に至り死亡した 1 例. 柬薬療法 18: 139-143 1999.

4）金川昭啓：病院歯科における口腔感染症治療. 口腔 感染症誌 9: 31-33 2002

5) Stevens, D.L., Bisno, A.L., et al.: Practice guidelines for the diagnosis and management of skin and softtissue infections. Clinical Infectious Diseases 41: 1373-1406 2005.

6) 西川邦男：咀嚼筋間隙と側頭間隙の解剖と画像診 断. JOHNS 14: 672-676 1998.

7）市村恵一：筋膜と（筋膜間）隙. JOHNS 14: 629-638 1998.

8）鈴木賢二：頸椎と咽後間隙の解剖と画像診断. JOHNS 14: 668-671 1998.

9）日本化学療法学会，日本嫌気性菌感染症研究会編： 嫌気性菌感染症 診断・治療ガイドライン. 第 1 版, 協和企画, 東京, 2007, 181-182 頁.

10) Umeda, M., Minamikawa, T., et al.: Necrotizing fasciitis caused by dental infection: A retrospective analysis of 9 cases and a review of the literature. Oral Surg Oral Med Oral Pathol Radiol Endod 95: 283-290 2003.

11）南川 勉, 梅田正博, 他：頭頸部壊死性筋膜炎の治 療法打よび予後：自験例 12 例と本邦報告例 111 例 の臨床的検討. 日口診誌 16: 239-245 2003. 